\title{
Accumulation of metal radiotracers by Mytilus edulis
}

\author{
C. Nolan ${ }^{1}$, H. Dahlgaard ${ }^{2}$ \\ ${ }^{1}$ IAEA International Laboratory of Marine Radioactivity, 19 Avenue des Castellans, MC-98000, Monaco \\ ${ }^{2}$ RIS $\oslash$ National Laboratory, Roskilde, DK-4000, Denmark
}

\begin{abstract}
Marine mussels Mytilus edulis accumulate radionuclides of cobalt, zinc, ruthenium, silver and caesium in the soft tissues linearly over time during exposure periods up to $9 \mathrm{~d}$. Radiotracer binding to shell is rapid, but variable, and is essentially complete after $1 \mathrm{~d}$. The distribution between soft tissues and shell varies with each metal and exposure period, and ranges from $1: 25$ for caesium and silver to $1: 1$ for cobalt after 9 d. Radiotracer contents of all isotopes in the mussels are lognormally distributed. Radionuclide contents after exposure increase with shell length and are best described by power functions of body weight. After $9 \mathrm{~d}$ of exposure both ruthenium and silver exhibit a typical surface-type behaviour, where the metal content of the mussels is proportional to their surface area. By contrast, cobalt, zinc and caesium exhibit a metabolic-type behaviour. The effect of inherent variability of the mussel population with respect to the accumulation of the radiotracers is discussed, as are implications for sampling programmes.
\end{abstract}

\section{INTRODUCTION}

Edible mussels Mytilus edulis have been widely used in marine monitoring programmes as indicators of pollution (Fowler \& Oregioni 1976, Marchand et. al. 1976 , Phillips 1976a, b, 1980, Goldberg et al. 1983). Soft tissues, shells, and even byssal threads have been proposed as indicators (Hamilton \& Clifton 1980, Koide et al. 1982, Goldberg et al. 1983). The use of bioindicators and problems associated with their application in aquatic monitoring programmes have been discussed by many authors, notably Phillips (1980). Advantages of their use include (1) ease of analysis, since they concentrate pollutants from ambient waters, (2) the obtainment of integrated records, since levels of contaminants in the animals do not fluctuate as widely as those in the surrounding water and tend to persist after a source of pollution has disappeared, (3) the levels in the animals can be used to better estimate biologically significant rather than total levels of contaminants, (4) food-chain transfer to predators including man may be estimated, (5) their sessile nature allows long-term field studies to be completed and trends in pollutant levels to be identified, and (6) the widespread distribution of Mytilus spp. permits comparisons to be made of pollutant levels in different areas.

Metal concentrations in mussels and other organisms may be modulated by a host of environmental and biological factors. Examples of the former include metal levels in food and water, season, salinity, position in the water column, temperature, food supply and the presence of other contaminants (Frazier 1975, Phillips 1976a, b, Wright 1978, Boyden \& Phillips 1981, Dahlgaard 1986). Biological factors affecting metal levels in mussels include condition, growth rate, sex, size and maturation (Pringle et al. 1968, Cossa et al. 1979, Ray 1984). Since these levels represent a steady state between accumulation and excretion, quantitative data on processes and factors affecting them are essential to correlate contaminant levels in the mussels with environmental levels, and also to distinguish spatial and temporal trends arising from pollutant inputs from those due to variability in biological responses to natural processes.

Cobalt and zinc, in contrast to ruthenium, silver and caesium, are essential elements for mussels. Cobalt is an essential component of vitamin $\mathrm{B}_{12}$ and an important cofactor for several enzymes, and zinc is required by a variety of biological molecules including enzymes and structural proteins (Lehninger 1976). Silver, like zinc, is a group II metal but is not known to have any biological functions in mussels. It is present in municipal waste discharges and, because of its accumulation by them, mussels have been proposed as bioindicators of such 
discharges (Martin et al. 1988). Caesium is a wellknown analogue of potassium and has been reported to be accumulated by animals by substitution during uptake processes (Вгуan 1963). The radionuclides of these metals are all present in discharges from nuclear power stations and reprocessing plants (CEC 1989). In addition, ${ }^{106} \mathrm{Ru},{ }^{106} \mathrm{Ag},{ }^{134} \mathrm{Cs}$ and ${ }^{137} \mathrm{Cs}$ are present in fallout deposition from weapons testing and from the Chernobyl accident (CEC 1989).

We have completed a series of studies on factors affecting accumulation and excretion of heavy metals, rare earths and transuranic radionuclides in the edible mussel Mytilus edulis. These factors include salinity, size, temperature, season, food supply and geographic location. Results from some of these studies - performed under Baltic conditions - have been published (Dahlgaard 1981, 1986). In this paper we report the results of experiments where the accumulation of cobalt, zinc, ruthenium, caesium and silver radiotracers in $M$. edulis under Mediterranean conditions was studied. The effect of organism size on uptake is examined and the results are compared with those of experiments performed previously at lower salinities and temperatures (Dahlgaard 1981, 1986).

\section{MATERIALS AND METHODS}

Commercially reared edible mussels Mytilus edulis from Sête on the French Mediterranean coast were purchased, cleaned of epifauna and byssal threads and sorted into 4 groups on the basis of shell length (Table 1). Only smooth-shelled specimens were selected. They were acclimatised to laboratory conditions (flowing $10 \mu \mathrm{m}$ filtered seawater at $16^{\circ} \mathrm{C}$ and $37 \%$ salinity) for 2 wk before use. Although no food was added to the aquaria, the flowing seawater contained appreciable amounts of nutrient material (evidenced by the continuous production of faeces by the mussels during this period). A total of 197 mussels of shell length $40.9 \pm 1.5 \mathrm{~mm}$ were denoted as Group I. The mussels in Groups II, III and IV, also selected on the basis of shell length, were individually numbered and individual shell lengths and total body weights (in-shell) were recorded.

The radionuclides ${ }^{60} \mathrm{Co},{ }^{65} \mathrm{Zn},{ }^{106} \mathrm{Ru},{ }^{134} \mathrm{Cs}$ and ${ }^{110} \mathrm{Ag}$ were purchased from Amersham plc (UK). Stock solutions containing ${ }^{60} \mathrm{Co},{ }^{65} \mathrm{Zn},{ }^{106} \mathrm{Ru}$ and ${ }^{134} \mathrm{Cs}$ were prepared with $1.5 \mathrm{~N} \mathrm{HCl}$. A separate stock solution of ${ }^{110} \mathrm{Ag}$ was prepared in $2 \mathrm{~N} \mathrm{HNO}_{3}$. Radioactivities were determined using a high-resolution gamma-spectrometry system comprising a $3 \times 3^{\prime \prime}(7.6 \times 7.6 \mathrm{~cm})$ coaxial $\mathrm{Ge}(\mathrm{Li})$ detector connected to a multichannel analyser and personal computer with spectral analysis software (Intertechnique, Grenoble). Appropriate standards were used to correct for geometry, efficiency and radiotracer decay.

Generally, mussels were exposed to the radiotracers in $20 \mathrm{l}$ aerated filtered seawater in plastic basins. The mussels rested on nylon meshes $(5 \mathrm{~mm}$ grid) which were fixed $5 \mathrm{~cm}$ above the bottom of each basin. The water was changed every $2 \mathrm{~d}$ and the radiotracer concentrations replenished by addition of $1 \mathrm{ml}$ of each of the 2 stock solutions. Small quantities of phytoplankton (Dunaliella tertiolecta) were continuously added to the basins using a peristaltic pump so as not to exceed a cell concentration of $10^{6}$ cells $l^{-1}$. It had been previously reported that the presence of algal cells in the water encourages mussels to filter greater quantities of water than they would in the absence of particulate material (Dahlgaard 1981). Daily variations in the concentrations of radiotracers in the water were monitored.

Group I mussels were exposed to the radiotracers for 9 d. Starting conditions were 65 or 66 mussels in 3 aquaria, each containing $20 \mathrm{l}$ aerated seawater with the following introduced radiotracer concentrations: ${ }^{60} \mathrm{Co}$, $8.5 \mathrm{kBq} \mathrm{l}^{-1}\left(1.47 \mathrm{pg}\right.$ added $\left.\mathrm{Co}^{-1}\right) ;{ }^{65} \mathrm{Zn}, 9.0 \mathrm{kBq} 1^{-1}$ $\left(0.79 \mathrm{pg}\right.$ added $\left.\mathrm{Zn} \mathrm{l}^{-1}\right) ;{ }^{106} \mathrm{Ru}, 39 \mathrm{kBq} \mathrm{l}^{-1}$ (275 $\mathrm{ng}$ added $\left.\mathrm{Ru} \mathrm{l}^{-1}\right) ;{ }^{110} \mathrm{Ag}, 1.5 \mathrm{kBq} \mathrm{l}^{-1}$ (188 $\mathrm{ng}$ added $\left.\mathrm{Ag} \mathrm{l}^{-1}\right) ;$ and ${ }^{134} \mathrm{Cs}, 33 \mathrm{~Bq}^{-1}$ (77 $\mathrm{ng}$ added $\left.\mathrm{Cs} \mathrm{l}^{-1}\right)$. With the exception of ruthenium and silver, the quantities of stable metal carrier introduced to the aquaria were orders of magnitude lower than those commonly found in seawater (Hood \& Pytkowicz 1974, Bruland 1983). At 1,4,7 and 9

Table 1. Mytilus edulis. Characteristics of the 4 groups of mussels used in these experiments (mean \pm SD)

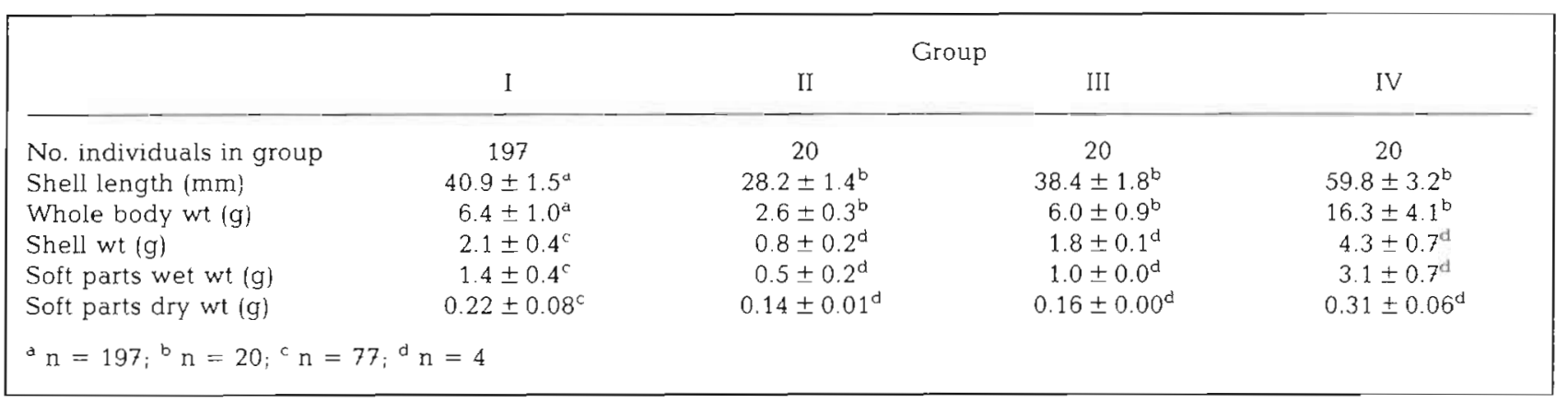


d of exposure, 9 or 10 mussels were randomly selected, and, after removal of the byssus from each specimen, rinsed in uncontaminated water, weighed and wholebody gamma-counted. These mussels were then dissected and the weights of the shell and wet soft parts determined. Shells were crushed and then dried with the soft parts, at $60^{\circ} \mathrm{C}$, to constant weight. The radioactivities were then measured. Accumulation of the radiotracers was expressed as the concentration factor $\left(\mathrm{CF}=\mathrm{Bq} \mathrm{g}{ }^{-1}\right.$ wet tissue $/ \mathrm{Bq} \mathrm{ml} l^{-1}$ water, where the time-integrated mean radiotracer concentration in the water was used). After $9 \mathrm{~d}$ of exposure, the remaining 159 mussels were removed and placed in flowing uncontaminated seawater for $12 \mathrm{~h}$. The length and weight of each specimen was recorded, the byssus removed, and the mussels were whole-body gammacounted.

Groups II, III and IV, each comprising 20 mussels, were placed in a single aquarium of $20 \mathrm{l}$ aerated filtered seawater containing the following introduced radiotracer concentrations: ${ }^{60} \mathrm{Co}, 1.5 \mathrm{kBq} \mathrm{l}{ }^{-1}(0.26 \mathrm{pg}$ added $\left.\mathrm{Co} \mathrm{l}^{-1}\right) ;{ }^{65} \mathrm{Zn}, 4.5 \mathrm{kBq} \mathrm{l}^{-1}\left(0.40 \mathrm{pg}\right.$ added $\left.\mathrm{Zn} \mathrm{l}^{-1}\right)$; ${ }^{106} \mathrm{Ru}, 31 \mathrm{kBq} \mathrm{l}{ }^{-1}\left(219 \mathrm{ng}\right.$ added $\left.\mathrm{Ru} \mathrm{l}{ }^{-1}\right) ;{ }^{110} \mathrm{Ag}, 20 \mathrm{kBq}$ $\mathrm{l}^{-1}\left(2.5 \mu \mathrm{g}\right.$ added $\left.\mathrm{Ag} \mathrm{l}^{-1}\right)$; and ${ }^{134} \mathrm{Cs}, 33 \mathrm{kBq} \mathrm{l^{-1 }}$ (77 ng added $\mathrm{Cs}^{-1}$ ). The amounts added differed from those used for Group I so as to facilitate interpretation of the gamma spectra. With the exception of silver, where the amounts of radioactivity added were more than 14 times greater than those used for Group I, and where the concentrations of stable carrier introduced with the radionuclide approached those commonly found in seawater, this did not result in a significant change in the stable element concentrations in the aquaria between the 2 exposures. Five individuals were selected from each group and their radioactivity con-

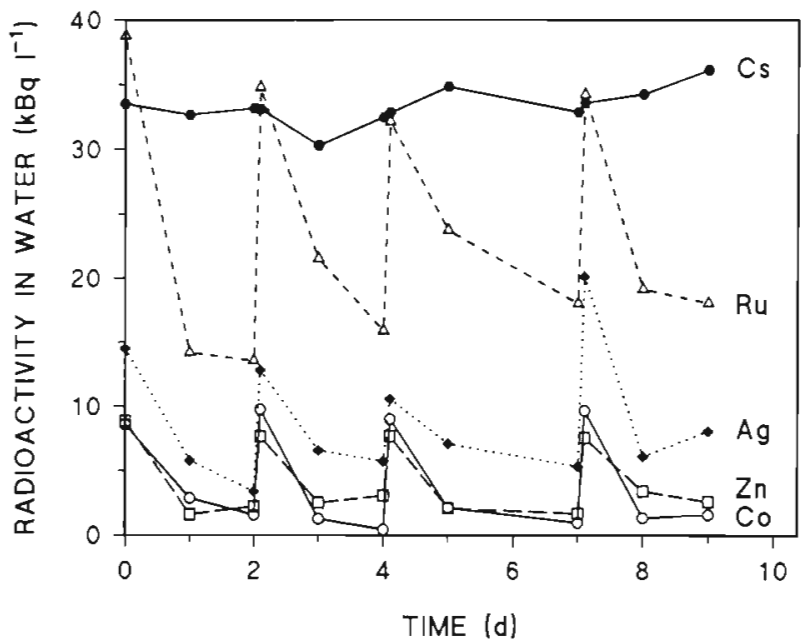

Fig. 1. Radiotracer concentrations $\left(\mathrm{kBq} \mathrm{l}^{-1}\right)$ in the water during exposure of Group I mussels to ${ }^{60} \mathrm{Co},{ }^{65} \mathrm{Zn},{ }^{106} \mathrm{Ru},{ }^{110} \mathrm{Ag}$ and ${ }^{134} \mathrm{Cs}$. For ease of comparison, data for ${ }^{110} \mathrm{Ag}$ are reported $\times 10$ tent determined by whole-body gamma-counting at $0.25,1,2,4$ and $8 \mathrm{~d}$ of exposure. The radioactivity in the water was replenished with fresh stocks when the water was changed after 2,4 and $7 \mathrm{~d}$. Accumulation was expressed as the CF vs time. After $8 \mathrm{~d}$ of exposure, the mussels were removed and placed in flowing uncontaminated seawater for $12 \mathrm{~h}$. They were then whole-body gamma-counted and the shell lengths and total body-weights determined. Four mussels were removed from each group and dissected into shell and soft parts. The wet weights of the soft parts were determined and the radioactivities in the weighed, crushed shells and in the dried soft parts were measured.

Statistical procedures and tests (estimation of means, $95 \%$ confidence limits, analysis of variance, Chi-square and Kolmogorov-Smirnov goodness-of-fit) were performed on the data, after log-transformation (natural logs) where appropriate, using a Statgraphics statistical software package (STSC, Rockville, MD, USA).

\section{RESULTS}

The concentrations of the radiotracers in the water during the exposure of the Group I mussels are shown in Fig. 1. Since the data from the second experiment have a similar pattern they are not shown. With the exception of ${ }^{134} \mathrm{Cs}$, there were considerable fluctuations in the radiotracer concentrations coincident with their uptake by the mussels and with their replenishment by fresh stocks each time the water was changed. The time-integrated mean concentrations of the radiotracers in the water during both experiments were respectively (Bq ml ${ }^{-1}$ ): ${ }^{60} \mathrm{Co}, 3.3$ and $1.0 ;{ }^{65} \mathrm{Zn}, 3.6$ and 3.4 ; ${ }^{106} \mathrm{Ru}, 22$ and $19 ;{ }^{110} \mathrm{Ag}, 0.8$ and $7.5 ;{ }^{134} \mathrm{Cs}, 33$ and 32.5 .

The uptake of each radiotracer by the shell and soft parts of the Group I mussels is shown in Fig. 2. Most of the uptake of the 5 radiotracers by shell occurred during the first few days of exposure, in contrast to soft parts wherein the radiotracers were accumulated linearly over time. The percentage of the total activity bound which was associated with the shell decreased with time for each metal. After $1 \mathrm{~d} 75 \%$ of the bound ${ }^{60} \mathrm{Co}$ was associated with the shell but by the final day it represented only $50 \%$. Similarly, for ${ }^{65} \mathrm{Zn}$, the $44 \%$ bound after $1 \mathrm{~d}$ was reduced to $25 \%$ at the end of the experiment. For ${ }^{106} \mathrm{Ru}$, the value of $50 \%$ at $1 \mathrm{~d}$ was almost halved to $28 \%$ by the 9th day due to the accumulation in the soft parts. Both ${ }^{110} \mathrm{Ag}$ and ${ }^{134} \mathrm{Cs}$ were preferentially accumulated by soft parts rather than shell. For ${ }^{110} \mathrm{Ag}$, the $11 \%$ on the shell after $1 \mathrm{~d}$ was reduced to $5 \%$ after $9 \mathrm{~d}$. The corresponding values for ${ }^{134} \mathrm{Cs}$ were $10 \%$ and $3 \%$ respectively. There were no significant $(p<0.01)$ differences between Groups II, III 


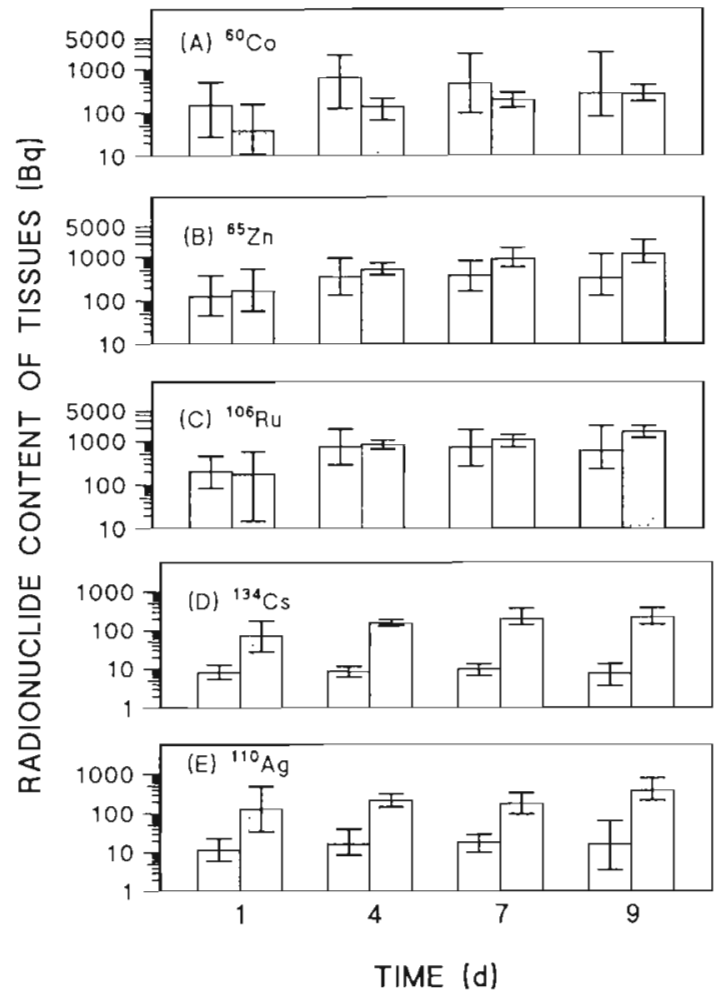

Fig. 2. Mytilus edulis. Uptake of $(\mathrm{A}){ }^{60} \mathrm{Co},(\mathrm{B}){ }^{65} \mathrm{Zn},(\mathrm{C}){ }^{106} \mathrm{Ru}$, (D) ${ }^{134} \mathrm{Cs}$ and (E) ${ }^{110} \mathrm{Ag}$ by shell (open) and soft parts (shaded) of Group I mussels during exposure to the radiotracers for up to $9 \mathrm{~d}$. Values reported are geometric means of radiotracer content $(\mathrm{Bq})$ for analyses of 10 individuals. Ranges of values measured are also shown

and IV in the percentage of the total radioactivity associated with shell after $9 \mathrm{~d}$. The percentages of total activity bound to the shell for the pooled mussels of Groups II, III and IV were (mean \pm SEM, $\mathbf{n}=12$ ): ${ }^{60} \mathrm{Co}$, $42 \pm 6 \% ;{ }^{65} \mathrm{Zn}, 17 \pm 2 \% ;{ }^{105} \mathrm{Ru}, 11 \pm 1 \% ;{ }^{110} \mathrm{Ag}, 9 \pm$ $1 \%$; and ${ }^{134} \mathrm{Cs}, 4 \pm 1 \%$.

Radiotracer uptake by soft parts and shell of Group I mussels is reported in Table 2. Accumulation by soft parts was linear over time for all radiotracers, as indicated by the positive slopes of the linear regression lines (all significantly different from zero at $p<0.0001$ ). There was probably a rapidly-exchanging compartment in the soft parts, since all 5 have a positive intercept (though only significantly different from zero for ${ }^{134} \mathrm{Cs}$ ). ${ }^{65} \mathrm{Zn}$ and ${ }^{110} \mathrm{Ag}$ were accumulated at similar rates, which were about 4.5 times faster than those of ${ }^{60} \mathrm{Co}$ and ${ }^{106} \mathrm{Ru}$. These in turn were 12 to 15 times greater than that of ${ }^{134} \mathrm{Cs}$. Variability for soft parts was considerable, as evidenced by the $95 \%$ confidence intervals in Table 2, but was generally less than that in shells (Table 2).

Accumulation rates of the radiotracers by the shells after the first day of exposure were positive but were not significantly different from zero $(p<0.0001)$. By contrast, soft parts accumulated ${ }^{65} \mathrm{Zn} 44$ times more rapidly than shell. Corresponding values for ${ }^{106} \mathrm{Ru}$ and ${ }^{110} \mathrm{Ag}$ were 30 and 300 , respectively. The intercepts of all 5 radiotracers were significantly greater than the rates, indicating that binding of radiotracers was rapid and that a steady state between uptake and loss was reached after $1 \mathrm{~d}$. The large variability in CF in shell was responsible for the low correlation coefficients.

Results of analysis of the 159 mussels in Group I are shown in Fig. 3. The mean weight is used and, to facilitate comparison with Groups II, III and IV, the normalised whole body radiotracer contents. The ${ }^{60} \mathrm{Co}$ and ${ }^{65} \mathrm{Zn}$ activities were identical in both experiments, but contents of ${ }^{134} \mathrm{Cs},{ }^{106} \mathrm{Ru}$ and ${ }^{110} \mathrm{Ag}$ in Group I mussels were lower than predicted from exposure of the other 3 groups $(p<0.05)$, although considerable overlap existed between the ranges of activities measured

Radionuclide uptake by the mussels in Group II, III and IV, as whole-body CF vs time, is shown in Table 3. Since accumulation was monitored by repeated measurements of the same specimens in each group, individual uptake rates could be determined by linear regression analysis for each mussel. In Table 3 the mean uptake rate $\left(\delta \mathrm{CF} \mathrm{d}^{-1} \pm \mathrm{SEM}\right)$ and the intercept $\left( \pm\right.$ SEM) are given for each group for ${ }^{65} \mathrm{Zn},{ }^{106} \mathrm{Ru}$ and ${ }^{134} \mathrm{Cs}$. The variability of the ${ }^{60} \mathrm{Co}$ and the ${ }^{110} \mathrm{Ag}$ data precluded the estimation of individual rates. The results for these 2 radiotracers are therefore reported for linear regression analyses of the pooled data in each group. Radiotracer concentrations increased linearly with time for ${ }^{60} \mathrm{Co},{ }^{65} \mathrm{Zn},{ }^{106} \mathrm{Ru}$ and ${ }^{134} \mathrm{Cs}$ in each group $(p<0.01)$. After the initial uptake of ${ }^{110} \mathrm{Ag}$ no further accumulation occurred. There was no significant group effect on accumulation rates of the 5 radiotracers after normalising for body weight $(p<0.01)$. Positive intercepts (not significantly different from zero for ${ }^{60} \mathrm{Co}$, $p<0.01$ ) were found for all radiotracers, indicating either an initial adsorption to the shell or uptake by a rapidly-exchanging pool in the soft parts. The only group effect on the intercepts was noted for ${ }^{134} \mathrm{Cs}$, where that of the largest mussels was significantly greater than those of the other 2 groups.

Chi-square and Kolmogorov-Smirnov goodness-offit tests indicated that length and weight data are adequately treated as being normally distributed, but that whole-body radiotracer contents are best described by lognormal distributions (data not shown). The coefficient of variation (CV) varied from $4 \%$ for length and $16 \%$ for weight to $29 \%$ for ${ }^{65} \mathrm{Zn}, 33 \%$ for ${ }^{106} \mathrm{Ru}, 39 \%$ for ${ }^{134} \mathrm{Cs}, 54 \%$ for ${ }^{110} \mathrm{Ag}$ and $87 \%$ for ${ }^{60} \mathrm{Co}$. Because of the large CV of uptake of each radiotracer it is possible that one or more Type II errors were made when testing for group effects on uptake. Support for this hypothesis is provided by the results of the whole-body gamma- 
Table 2. Mytilus edulis. Mean concentration factors (CF) of ${ }^{60} \mathrm{Co}{ }^{65} \mathrm{Zn},{ }^{106} \mathrm{Ru},{ }^{110} \mathrm{Ag}$ and ${ }^{134} \mathrm{Cs}$ in the soft parts and in the shell after $1,4,7$ or $9 \mathrm{~d}$ of exposure. The $95 \%$ confidence intervals for each radionuclide are given in parentheses. The results of a linear regression analysis for each radiotracer $(n=47)$ of $C F$ vs days of exposure are also reported

\begin{tabular}{|c|c|c|c|c|c|c|c|}
\hline \multirow[t]{2}{*}{ Radionuclide } & \multicolumn{4}{|c|}{ Days of exposure } & \multicolumn{3}{|c|}{ Linear regression } \\
\hline & 1 & 4 & 7 & 9 & Intercept & Slope & $\mathrm{R}^{2}$ \\
\hline \multicolumn{8}{|l|}{ Soft parts } \\
\hline${ }^{60} \mathrm{Co}$ & $\begin{array}{c}60 \\
(15-239)\end{array}$ & $\begin{array}{c}215 \\
(101-459)\end{array}$ & $\begin{array}{c}287 \\
(159-518)\end{array}$ & $\begin{array}{c}420 \\
(197-896)\end{array}$ & 42 & $39^{\circ}$ & 0.67 \\
\hline${ }^{65} \mathrm{Zn}$ & $\begin{array}{c}243 \\
(97-610)\end{array}$ & $\begin{array}{c}738 \\
(545-999)\end{array}$ & $\begin{array}{c}1161 \\
(575-2344)\end{array}$ & $\begin{array}{c}1636 \\
(1140-2348)\end{array}$ & 73 & $172^{\circ}$ & 0.80 \\
\hline${ }^{106} \mathrm{Ru}$ & $\begin{array}{c}40 \\
(4-400)\end{array}$ & $\begin{array}{c}195 \\
(128-297)\end{array}$ & $\begin{array}{c}231 \\
(135-394)\end{array}$ & $\begin{array}{c}383 \\
(238-617)\end{array}$ & 24 & $38^{\circ}$ & 0.72 \\
\hline${ }^{110} \mathrm{Ag}$ & $\begin{array}{c}860 \\
(186-3972)\end{array}$ & $\begin{array}{c}1424 \\
(835-2429)\end{array}$ & $\begin{array}{c}1064 \\
(402-2816)\end{array}$ & $\begin{array}{c}2550 \\
(1196-5439)\end{array}$ & 603 & $160^{\circ}$ & 0.40 \\
\hline${ }^{134} \mathrm{Cs}$ & $\begin{array}{c}11 \\
(5-22)\end{array}$ & $\begin{array}{c}24 \\
(21-27)\end{array}$ & $\begin{array}{c}28 \\
(20-40)\end{array}$ & $\begin{array}{c}34 \\
(27-43)\end{array}$ & $10^{\circ}$ & $3^{\circ}$ & 0.81 \\
\hline \multicolumn{8}{|l|}{ Shell } \\
\hline${ }^{60} \mathrm{Co}$ & $\begin{array}{c}28 \\
(6-142)\end{array}$ & $\begin{array}{c}99 \\
(12-797)\end{array}$ & $\begin{array}{c}72 \\
(6-889)\end{array}$ & $\begin{array}{c}43 \\
(8-218)\end{array}$ & 67 & 4.6 & 0.02 \\
\hline${ }^{65} \mathrm{Zn}$ & $\begin{array}{c}19 \\
(6-56)\end{array}$ & $\begin{array}{c}50 \\
(10-242)\end{array}$ & $\begin{array}{c}52 \\
(17-161)\end{array}$ & $\begin{array}{c}48 \\
(17-134)\end{array}$ & 28 & 3.9 & 0.12 \\
\hline${ }^{106} \mathrm{Ru}$ & $\begin{array}{c}5.2 \\
(2-15)\end{array}$ & $\begin{array}{c}17 \\
(4-79)\end{array}$ & $\begin{array}{c}16 \\
(4-61)\end{array}$ & $\begin{array}{c}14 \\
(5-41)\end{array}$ & 8.9 & 1.3 & 0.11 \\
\hline${ }^{110} \mathrm{Ag}$ & $\begin{array}{c}8 \\
(4-16)\end{array}$ & $\begin{array}{c}11 \\
(3-38)\end{array}$ & $\begin{array}{c}11 \\
(6-21)\end{array}$ & $\begin{array}{c}11 \\
(5-26)\end{array}$ & $8.0^{\circ}$ & 0.5 & 0.17 \\
\hline${ }^{134} \mathrm{Cs}$ & $\begin{array}{c}0.14 \\
(0.08-0.24)\end{array}$ & $\begin{array}{c}0.10 \\
(0.04-0.23)\end{array}$ & $\begin{array}{c}0.15 \\
(0.10-0.22)\end{array}$ & $\begin{array}{c}0.12 \\
(0.06-0.26)\end{array}$ & $0.14^{\circ}$ & 0.0 & 0.00 \\
\hline
\end{tabular}

Table 3. Mytilus edulis. Accumulation of ${ }^{60} \mathrm{Co},{ }^{65} \mathrm{Zn},{ }^{106} \mathrm{Ru},{ }^{110} \mathrm{Ag}$ and ${ }^{134} \mathrm{Cs}$ in Groups II, III and IV expressed as whole-body (combined shell and soft parts) concentration factors (CF) after $0.25,1,2,4$ and $8 \mathrm{~d}$ of exposure. Values are means of 5 mussels. In addition, the CFs determined for 16 mussels from each group after $8 \mathrm{~d}$ exposure followed by $12 \mathrm{~h}$ loss in flowing uncontaminated water are reported. Also shown are the calculated mean linear uptake rates determined using linear regression of the results of the repeated analyses of the 5 selected mussels from each group vs days of exposure. For ${ }^{60} \mathrm{Co}$ and ${ }^{110} \mathrm{Ag}$ values are for linear regression analyses of the pooled data from 5 mussels in each group since there was no discernible trend in any individual due to the variability of the data

\begin{tabular}{|c|c|c|c|c|c|c|c|c|c|}
\hline \multirow[t]{2}{*}{ Radionuclide } & \multirow[t]{2}{*}{ Group } & \multicolumn{6}{|c|}{ Days of exposure } & \multicolumn{2}{|c|}{ Linear regression } \\
\hline & & 0.25 & 1 & 2 & 4 & 8 & Loss & Intercept & Slope \\
\hline \multirow[t]{3}{*}{${ }^{60} \mathrm{Co}$} & II & ND & ND & 38 & 38 & 80 & 45 & $10 \pm 20^{c}$ & $9.0 \pm 2.7$ \\
\hline & III & ND & 21 & 21 & 46 & 69 & 45 & $12 \pm 15^{c}$ & $7.7 \pm 1.5$ \\
\hline & IV & 15 & 21 & 30 & 54 & 82 & 34 & $15 \pm 18^{\mathrm{c}}$ & $9.1 \pm 1.4$ \\
\hline \multirow[t]{3}{*}{${ }^{65} \mathrm{Zn}$} & II & 28 & 41 & 49 & 107 & 123 & 87 & $32 \pm 5$ & $13.5 \pm 1.7$ \\
\hline & III & 19 & 31 & 49 & 101 & 126 & 73 & $24 \pm 5$ & $14.3 \pm 0.7$ \\
\hline & IV & 30 & 51 & 55 & 109 & 139 & $61^{\mathrm{b}}$ & $34 \pm 2$ & $14.9 \pm 1.9$ \\
\hline \multirow[t]{3}{*}{${ }^{106} \mathrm{Ru}$} & II & 48 & 45 & 66 & 75 & 84 & $64^{\mathrm{b}}$ & $46 \pm 2$ & $6.4 \pm 1.3$ \\
\hline & III & 37 & 37 & 41 & 56 & 78 & $49^{a}$ & $32 \pm 2$ & $5.5 \pm 1.2$ \\
\hline & IV & 34 & 50 & 50 & 54 & 85 & $32^{\mathrm{a}}$ & $37 \pm 4$ & $5.2 \pm 0.6$ \\
\hline \multirow[t]{3}{*}{${ }^{110} \mathrm{Ag}$} & II & 349 & 314 & 311 & 333 & 328 & $255^{b}$ & $325 \pm 41$ & $0 \pm 3^{c}$ \\
\hline & III & 196 & 192 & 184 & 201 & 188 & $177^{a}$ & $198 \pm 45$ & $0 \pm 3^{\mathrm{c}}$ \\
\hline & IV & 243 & 231 & 217 & 245 & 217 & $115^{a b}$ & $240 \pm 33$ & $-2 \pm 2^{c}$ \\
\hline \multirow[t]{3}{*}{${ }^{134} \mathrm{Cs}$} & II & 2.0 & 2.6 & 3.4 & 3.7 & 4.6 & 2.2 & $2.4 \pm 0.3$ & $0.32 \pm 0.03$ \\
\hline & III & 1.9 & 2.5 & 2.9 & 3.3 & 4.0 & 2.3 & $2.2 \pm 0.1$ & $0.25 \pm 0.02$ \\
\hline & IV & 2.8 & 3.4 & 3.7 & 4.4 & 4.8 & $1.4^{a b}$ & $3.1 \pm 0.1^{\mathrm{ab}}$ & $0.25 \pm 0.01$ \\
\hline
\end{tabular}

ND: not detected; ${ }^{a}$ Significantly different from Group II $(p<0.05) ;{ }^{b}$ Significantly different from Group III $(p<0.05) ;{ }^{c}$ Not significantly different from zero $(p<0.05)$ 

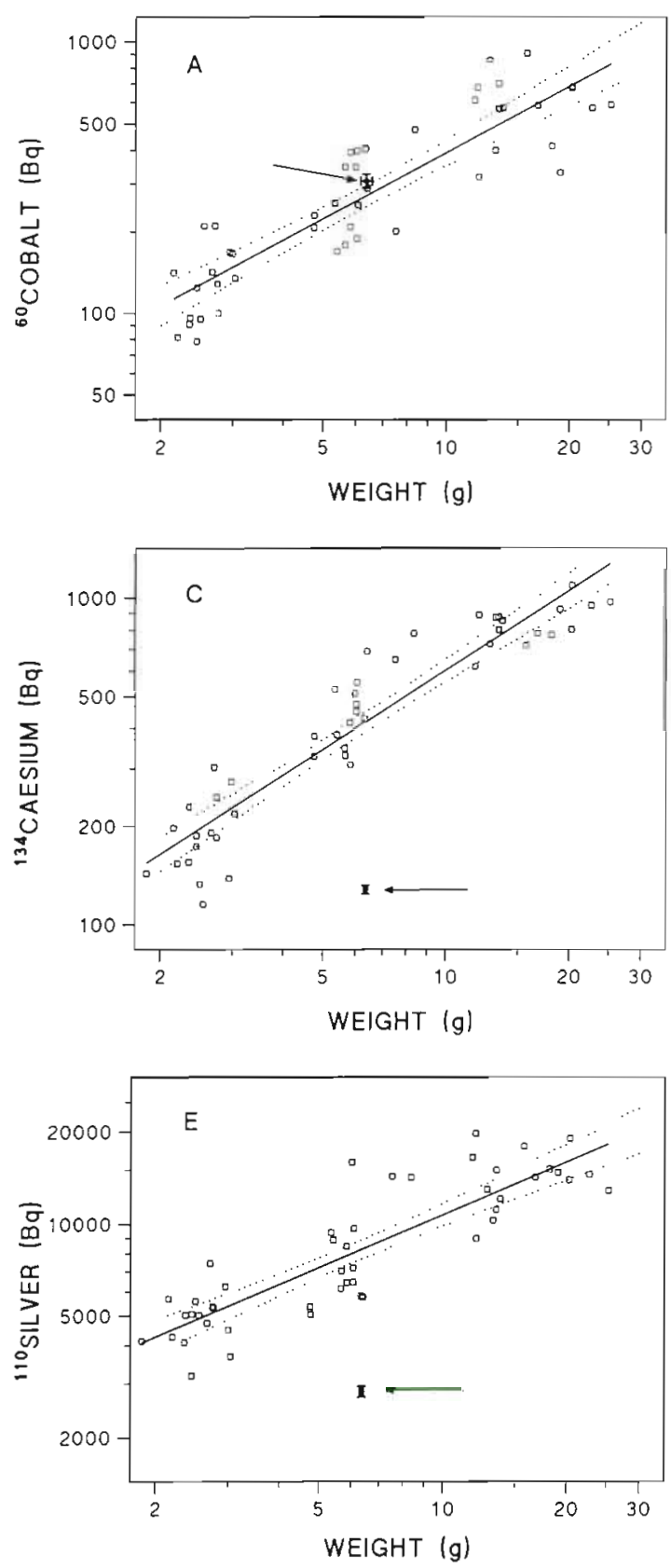

counting of 16 mussels from each of Groups II, III and IV after $8 \mathrm{~d}$ of exposure followed by $12 \mathrm{~h}$ of excretion in uncontaminated flowing seawater (Table 3). Statistical analysis of variance of these latter data showed a significant $(p<0.005)$ group effect on $\mathrm{CF}$ for ${ }^{65} \mathrm{Zn},{ }^{106} \mathrm{Ru}$, ${ }^{110} \mathrm{Ag}$ and ${ }^{134} \mathrm{Cs}$ with smaller specimens having greater CFs than larger ones.

Table 4 presents the estimated sample sizes required to detect changes in radiotracer content of 10 , 20 and $50 \%$ in a population of mussels with coefficients of variation for each radiotracer similar to those noted for Group I. Sample sizes of up to hundreds of mussels would be required to detect changes of $10 \%$,
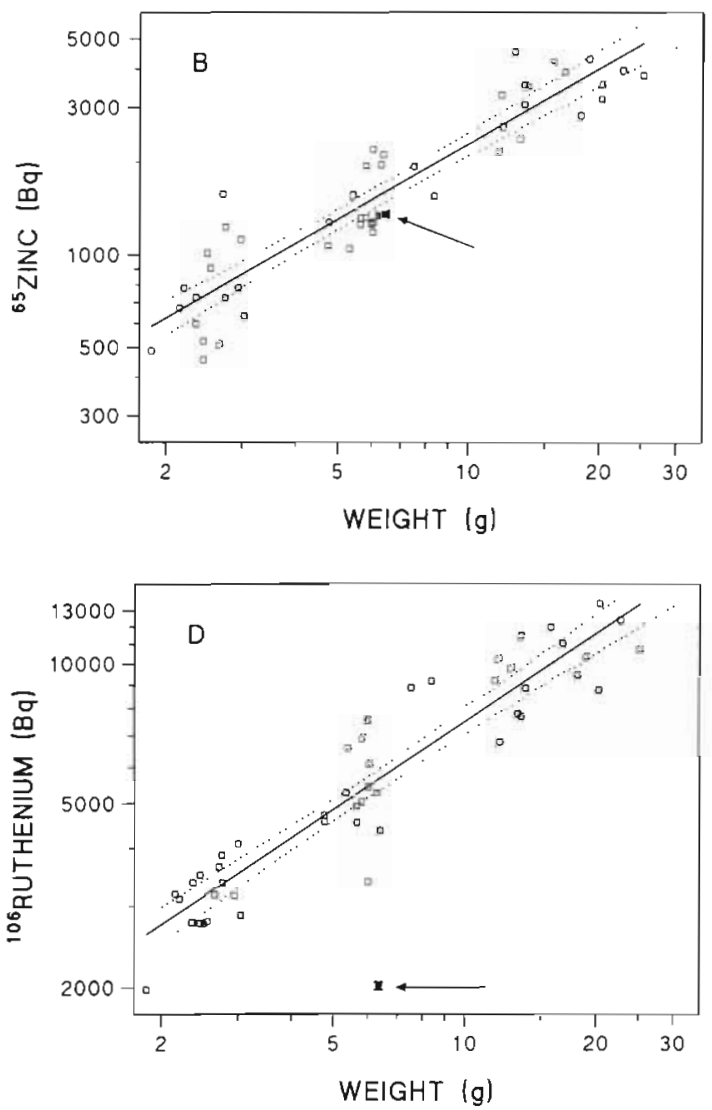

Fig. 3. Mytilus edulis. Regression (with $95 \%$ confidence intervals on the means) of $\log _{e}$ radiotracer content $(\mathrm{Bq})$ on $\log _{e}$ whole-body (shell and soft parts) weight ( $g$ ) for 48 mussels (Groups II, III and IV) exposed for $8 \mathrm{~d}$ to (A) ${ }^{60} \mathrm{Co},(\mathrm{B}){ }^{65} \mathrm{Zn},(\mathrm{C})$ ${ }^{134} \mathrm{Cs}$, (D) ${ }^{106} \mathrm{Ru}$ and $(\mathrm{E}){ }^{110} \mathrm{Ag}$ followed by $12 \mathrm{~h}$ loss in flowing uncontaminated water. The best fit equations describing the regression lines are $(\mathrm{A}) \log _{e}\left({ }^{60} \mathrm{Co}\right)=(4.1 \pm 0.1)+(0.81 \pm 0.06)$ $\times \log _{e}($ Weight $\left.), R^{2}=0.793 ;(B) \log _{e}{ }^{65} \mathrm{Zn}\right)=(5.9 \pm 0.1)+(0.81$ $\pm 0.05) \times \log _{e}($ Weight $), R^{2}=0.862 ;(C) \log _{e}\left({ }^{134} \mathrm{Cs}\right)=(4.5 \pm$ $0.1)+(0.81 \pm 0.03) \times \log _{e}($ Weight $), R^{2}=0.883 ;(D) \log _{e}\left({ }^{106} R u\right)$ $=(7.5 \pm 0.1)+(0.63 \pm 0.03) \times \log _{e}($ Weight $), R^{2}=0.881 ;(E)$ $\log _{e}\left({ }^{110} \mathrm{Ag}\right)=(8.0 \pm 0.1)+(0.57 \pm 0.05) \times \log _{e}($ Weight $), R^{2}=$ 0.758 . Mean weight and radionuclide contents ( \pm SEM) of the Group I mussels are indicated by arrows

but 20 mussels or less would be adequate to detect changes of $20 \%$ for ${ }^{65} \mathrm{Zn}$ and ${ }^{106} \mathrm{Ru}$ and of $50 \%$ for the other 3 radionuclides. It can also be seen from Table 4 that the sample size of 5 , used to monitor radiotracer uptake by Groups II, III and IV, was inadequate to test for between-group differences as great as $50 \%$ in ${ }^{60} \mathrm{Co},{ }^{134} \mathrm{Cs}$ and ${ }^{110} \mathrm{Ag}$ content since the probability of committing a Type II error exceeds $25 \%$ in these cases. The sample size of 16 used at the end of the exposure period was adequate for testing of all radiotracers except ${ }^{60} \mathrm{Co}$ at $\mathrm{p}<0.05$. Group differences were found for ${ }^{106} \mathrm{Ru},{ }^{134} \mathrm{Cs},{ }^{110} \mathrm{Ag}$ and ${ }^{65} \mathrm{Zn}$ but not for ${ }^{60}$ Co (Table 3 ). 
Table 4. Mytilus edulis. Sample sizes required to detect changes in radionuclide content in a population of homogeneous shell length. Values presented are estimated so that increases of 10,20 and $50 \%$ in the radiotracer content of mussels would be detected with $95 \%$ confidence. Calculations are based on the variability of the log-transformed whole-body radiotracer contents of Group I mussels reported in the text. Also given are the probabilities of committing a Type II error when testing for differences in radiotracer content of $50 \%$ if sample sizes of 5,10 and 15 mussels were to be selected and if the probability of a Type I error were to be set at $5 \%$

\begin{tabular}{|c|c|c|c|c|c|c|}
\hline \multirow{2}{*}{ Isotope } & \multicolumn{3}{|c|}{ Sample size required to detect change of } & \multicolumn{3}{|c|}{$\%$ Probability of Type II error with sample size of } \\
\hline & $10 \%$ & $20 \%$ & $50 \%$ & 5 & 10 & 15 \\
\hline${ }^{60} \mathrm{Co}$ & 375 & 101 & 21 & 57 & 28 & 13 \\
\hline${ }^{65} \mathrm{Zn}$ & 41 & 11 & 3 & 0.2 & 0 & 0 \\
\hline${ }^{106} \mathrm{Ru}$ & 48 & 13 & 3 & 0.1 & 0 & 0 \\
\hline${ }^{134} \mathrm{Cs}$ & 184 & 50 & 10 & 28 & 5 & 3 \\
\hline${ }^{110} \mathrm{Ag}$ & 235 & 64 & 13 & 38 & 11 & 1 \\
\hline
\end{tabular}

The accumulation of the 5 radiotracers is satisfactorily described by a power function of radionuclide content on body weight (Content $=\mathrm{K} 1 \times$ Weight $^{\mathrm{K} 2}$ ) $($ Fig. 3) since regression plots of $\log _{e}$ radiotracer content vs $\log _{e}$ body weight are linear $(p<0.0001)$. The radionuclides can be separated into 2 classes on the basis of the exponents of the functions relating metal content to mussel size. The first class comprises ${ }^{60} \mathrm{Co}(0.81),{ }^{65} \mathrm{Zn}$ $(0.81)$ and ${ }^{134} \mathrm{Cs}(0.81)$ and the second contains the more surface-reactive ${ }^{106} \mathrm{Ru}(0.63)$ and ${ }^{110} \mathrm{Ag}(0.57)$. It is noteworthy that although ${ }^{106} \mathrm{Ru}$ and ${ }^{110} \mathrm{Ag}$ exhibited significantly lower slopes than the other radiotracers, their intercepts were significantly higher.

\section{DISCUSSION}

Although Mytilus edulis is a filter-feeder, few accumulation experiments have been reported where the mussels have been fed - uptake has more frequently been described as uptake from water (Pentreath 1973, Shimizu 1975). Riisgård \& Randløv (1981) reported decreased filtration rates of mussels during starvation, and Bayne (1976) reported altered metabolism of mussels under similar conditions. In our experiments, mussels were fed with Dunaliella tertiolecta and were actively filtering the water whenever examined. Since the filtered algal material contained bound radiotracer, some accumulation may have been from food. The upper limits of such uptake can be estimated. The mean residence time of each algal cell in the water was $20 \mathrm{~h}$, sufficient for about $80 \%$ of maximum binding to occur. A maximum of 5400 cells $\mathrm{h}^{-1}$, equivalent to $5.4 \mu \mathrm{g}$ of wet algal material, was filtered per $\mathrm{g}$ soft wet weight $M$. edulis $\mathrm{h}^{-1}$. Using CF data compiled by the IAEA (1985) of 5000 for Co, 30000 for Zn, 200000 for $\mathrm{Ru}, 20$ for $\mathrm{Cs}$ and 10000 for $\mathrm{Ag}$, and assuming that $100 \%$ of filtered material was assinilated by the mussels, uptake rates $\left(\delta \mathrm{CF} \mathrm{d} \mathrm{d}^{-1}\right)$ of $0.6(\mathrm{Co}), 3.8(\mathrm{Zn}), 25.7$ $(\mathrm{Ru}), 0.003(\mathrm{Cs})$ and $1.3(\mathrm{Ag})$ can be calculated. These are maximum values and correspond to $1.6 \%$ (Co), $2.2 \%(\mathrm{Zn}), 68 \%(\mathrm{Ru}), 0.1 \%(\mathrm{Cs})$ and $0.8 \%(\mathrm{Ag})$ of the total accumulation measured for Group I mussels. This result corroborates the reports of Dahlgaard (1981), who did not note any effect of feeding level on the accumulation of $\mathrm{Cr}, \mathrm{Mn}, \mathrm{Co}, \mathrm{Fe}, \mathrm{Zn}$ and $\mathrm{Cs}$ by $\mathrm{M}$. edulis. With the possible exception of ruthenium, the results reported here are consistent with an accumulation pattern dominated by water and not by uptake from food.

The rates of accumulation of ${ }^{60} \mathrm{Co},{ }^{65} \mathrm{Zn},{ }^{134} \mathrm{Cs}$ and ${ }^{110} \mathrm{Ag}$ are lower than those reported by Dahlgaard (1981, 1986) for similar experiments performed with Mytilus edulis at the lower salinities found in the Baltic Sea $(6 \%)$ and in Danish coastal waters $(16 \%)$. It is likely that the observed differences are due to both the increased rate of ion-exchange occurring at gill and mantle surfaces and the decreased competition of radiotracers with other ions for available binding sites at the lower salinities of the Baltic. Salinity effects on metal uptake by $M$. edulis have been documented by Phillips (1976a, b) and by Dahlgaard (1981). Accumulation of metals in aquatic animals, including mussels, has been reported to be positively correlated with temperature (Phillips 1976b, Nakahara et al. 1977) and, since the temperature used in these experiments was about $10^{\circ} \mathrm{C}$ higher than in those performed under 'Baltic' conditions, we would have expected greater accumulation rates (Dahlgaard 1981). We conclude that in the present experiments the salinity effect outweighed the temperature effect. Significant salinitytemperature interactions during accumulation of radionuclides have been reported by Dahlgaard (1981). Accumulation of ${ }^{106} \mathrm{Ru}$, which was added to the aquaria in a chloride solution, was similar to that reported for ruthenium chloro-complexes by Keckes et al. (1967), who found that ruthenium chloro-complexes are more rapidly accumulated by mussels than are nitrosocomplexes.

The lognormal distributions of radiotracer content in 
the mussels are similar to those for many metals in feral populations (Taguchi et al. 1979, Shimizu \& Tsuji 1980, Lobel et al. 1982, Wright et al. 1985, Lobel 1987). Logtransformation of such data permits statistical tests for trends, differences and changes in variance to be made (Eberhardt 1975). Even when confounding effects such as size, season and location (this study) and sex (Lobel 1987) are eliminated, the log-normal distribution often remains. The underlying cause of this behaviour has yet to be identified, and has been ascribed to genetic variation within populations and termed inherent variability (Lobel 1987). The variability reported here is not as great as that observed in the environment (Lobel et al. 1982), possibly because the short exposure period of $9 \mathrm{~d}$ was insufficient to allow inherent differences in response to exposure to become fully manifest. In welldesigned monitoring schemes the effects of confounding factors such as size, sex and age are minimised by careful design of sampling strategies, and sample sizes are selected only after an evaluation of the variability of the substance being sampled for in the test population (Gordon et al. 1980, Phillips 1980, Goldberg et al. 1983). This can vary widely for different contaminants. For example, 9 times as many mussels would need to be analysed to detect (with a confidence level of $95 \%$ ) a $10 \%$ or even a $20 \%$ change in ${ }^{60}$ Co content as would be needed for ${ }^{65} \mathrm{Zn}$ (Table 4 ), all other factors being accounted for.

For the Group I mussels, selected so as to be as homogeneous for size as possible, the CF varied by as much as an order of magnitude during uptake, particularly for the shells which, in these experiments, were clean and smooth. In natural populations each shell is a microecosystem, sustaining epiflora and epifauna, attached byssal threads etc. The pattern of uptake seen here for the shells is consistent with a surface adsorption mechanism with a rapid saturation of binding sites. Therefore, large sample sizes are required when using shells as indicators and care should be exercised in the interpretation of the results. Use of soft parts in monitoring is preferable to the use of shells, since the data are less variable and more biologically useful. Since the shells do not accumulate radiotracers with time, it should also be possible, from an analysis of whole-body (shell and soft parts combined) to estimate the uptake rates into the soft parts. The ratio of accumulation rates $\left(\delta \mathrm{CF} \mathrm{d} \mathrm{d}^{-1}\right)$ in the soft parts of Group I to the whole-body rates in Group III are quite similar to the ratio of soft parts wet weight to whole-body weight in these individuals. The advantages of whole-body analysis include less sample handling, less chance of sample contamination and, more importantly, the possibility of non-destructive sampling. Individual uptake and loss rates of radiotracers can be measured and some between-individual variability can be eliminated.
Among the disadvantages of whole-body analysis is that assumptions must be made about the distribution of radioactivity in the mussels and that the large variability of radiotracer binding to the shell can obscure the accumulation and loss by the soft parts. Thus, individual uptake rates could be measured here for ${ }^{65} \mathrm{Zn}$. ${ }^{106} \mathrm{Ru}$ and ${ }^{134} \mathrm{Cs}$ but not for ${ }^{60} \mathrm{Co}$ and ${ }^{110} \mathrm{Ag}$. Individual loss rates could also be calculated for each of the radiotracers in the mussels in Groups II, III and IV (Nolan \& Dahlgaard unpubl.).

Many biological processes are directly dependent on the size of the organism (Fenchel 1987). In Mytilus spp., the rates of filtration, growth, feeding and oxygen consumption etc. are a power function of body weight (Bayne 1976). Boyden (1974, 1977) and Phillips (1980) showed that the metal contents of aquatic molluscs can be described by power functions of body weight but that the exponent varied with season, location, metal and population. If accumulation were to be attributable to surface adsorption phenomena, it should be proportional to body weight raised to the power of 0.67 . Divergence from this ratio could be accounted for by an involvement of metabolic activity in metal uptake or exclusion.

We conclude, from the 2 classes of linear relationships (Fig. 3), that for ${ }^{106} \mathrm{Ru}$ and ${ }^{110} \mathrm{Ag}$, binding to available surfaces was the predominant mode of accumulation. This conclusion is supported by the kinetics of uptake where a relatively large percentage of the total uptake occurred during the first day of exposure (Table 3). When the tissue distributions of the radiotracers were examined, both ${ }^{106} \mathrm{Ru}$ and ${ }^{110} \mathrm{Ag}$ were found to be almost entirely associated with tissues which have surface areas exposed to the water: shell, gills and mantle (Nolan \& Dahlgaard unpubl.). The exponent of 0.81 found for ${ }^{60} \mathrm{Co},{ }^{65} \mathrm{Zn}$ and ${ }^{134} \mathrm{Cs}$ is not significantly different from the range of 0.75 to 0.80 commonly found for metabolic processes (Zeuthen 1953, Fenchel 1987), and it is likely that accumulation of these radionuclides is directly linked to the metabolism of the mussels. Size effects on loss rates have been reported for zinc in gastropods (Mishima \& Odum 1983), with smaller individuals losing zinc more quickly than larger ones. In experiments which followed those described here, no size effects were noted on loss rates of the 5 radiotracers and no difference in biological half-life was found between Group I mussels (loss in field) and Groups II, III and IV (loss in laboratory) (Nolan \& Dahlgaard unpubl.). It is thus likely that the equations relating radiotracer content to body weight would also hold at steady state. Since radiotracer content in the mussels is a function of their size, the variation of individual sizes within each of the Groups II, III and IV is the factor most likely to be responsible for the lack of strong group differences in radiotracer content after exposure (Table 3 ). There is 
good agreement between the values found for the essential metals ${ }^{60} \mathrm{Co}$ and ${ }^{65} \mathrm{Zn}$ in Group I at the end of the first experiment and those of the remaining mussels after the second experiment (Fig. 3). The agreement is reasonable for ${ }^{134} \mathrm{Cs}$ and ${ }^{110} \mathrm{Ag}$ but is not as good for ${ }^{106} \mathrm{Ru}$, although the ranges of values found after the 2 exposures overlap considerably. The ranges of values found after the first experiment are much greater than those of the second, probably due to the larger sample size analysed.

Individual size is an important factor to consider during the design of sampling strategies. A $10 \%$ increase in shell length can result in a $33 \%$ increase in body weight and a $26 \%$ increase in radiotracer content (Fig. 3A to C). Without careful control of the size ranges sampled, it would not be possible to detect changes of contaminant content between any 2 samplings of a test population. Unfortunately, many locations do not sustain populations large enough to permit collection of sufficient samples within a small size-range for adequate detection capability (Table 4). This dilemma and methods to surmount it are discussed by Phillips (1980)

We conclude that uptake of cobalt, zinc, ruthenium, caesium and silver in the soft parts of Mytilus edulis is linear over time, but that uptake by shell is rapid and essentially complete after $1 \mathrm{~d}$. In both cases, accumulation is variable and radionuclide contents are log-normally distributed. Since uptake is size-dependent, care must be taken in sampling programmes to restrict the size ranges sampled and to collect sufficient numbers of individuals if significant changes in metal content are to be identified. Accumulation is slower under Mediterranean conditions than at the lower salinities encountered in the Baltic Sea and in estuarine environments.

Acknowledgements. The IAEA International Laboratory of Marine Radioactivity operates under a bipartite agreement between the International Atomic Energy Agency and the Government of the Principality of Monaco. This work was supported in part by the Radiation Protection Research Programme of the Commission of the European Communities This support is gratefully acknowledged. The authors thank Dr S. W. Fowler for his many useful criticisms and advice Finally, we appreciate the efforts and patience of the anonymous referees of this manuscript.

\section{LITERATURE CITED}

Bayne, B. L. (1976). Marine mussels - their ecology and physiology. Cambridge University Press, Cambridge

Boyden, C. R. (1974). Trace element content and body size in molluscs. Nature, Lond. 251: 311-314

Boyden, C. R. (1977). Effect of size upon metal content of shellfish. J. mar. biol. Ass. U.K. 57: 675-714

Boyden, C. R., Phillips, D. J. H. (1981). Seasonal variation and inherent variability of trace elements in oysters and their implications for indicator studies. Mar Ecol. Prog. Ser. 5: $29-40$
Bruland, K. D. (1983). Trace elements in seawater. In: Riley, J. P., Chester, R. (eds.) Chemical aceanography 8. Academic Press, London, p. 157-220

Bryan, G. W. (1963). The accumulation of radioactive caesium by marine invertebrates. J. mar. biol. Ass. U.K. 43: 519-539

CEC (1989). The radiological exposure of the population of the European Community from radioactivity in North European marine waters - Project MARINA. Report EUR-12483, Commission of the European Communities, Brussels

Cossa, D., Bourget, E., Piuze, J. (1979). Sexual maturation as a source of variation in the relationship between cadmium concentration and body weight of Mytilus edulis L. Mar. Pollut. Bull. 10: 174-176

Dahlgaard, H. (1981). Bioindicators for monitoring radioactive pollution of the marine environment - experiments on the feasibility of Mytilus as a bioindicator in estuarine environments with some comparisons to Fucus. Risø Reports No. 15, Risø, Roskilde, Denmark

Dahlgaard, H. (1986). Effects of season and temperature on long-term in situ loss rates of $\mathrm{Pu}, \mathrm{Am}, \mathrm{Np}, \mathrm{Eu}, \mathrm{Ce}, \mathrm{Ag}, \mathrm{Tc}$, $\mathrm{Zn}, \mathrm{Co}$ and $\mathrm{Mn}$ in a Baltic Mytilus edulis population. Mar. Ecol. Prog. Ser. 33: 157-165

Eberhardt, L. L. (1975). Sampling for radionuclides and other trace substances. In: Cushing, C. E. (ed.) Radioecology and energy resources. Ecological Society of America Special Publication No. 1. Dowden, Hutchinson \& Ross Inc, Stroudsberg, p. 199-208

Fenchel, T (1987). Ecology - potentials and limitations. In: Kinne, O. (ed.) Excellence in ecology 1. Ecology Institute, Oldendort/Luhe

Fowler, S. W., Oregioni, B. (1976). Trace metals in mussels from the N.W. Mediterranean. Mar Pollut. Bull. 7. 26-29

Frazier, J. M. (1975). The dynamics of metals in the American oyster, Crassostrea virginica. I. Seasonal effects. Chesapeake Sci. 16: 162-173

Goldberg, E. D., Koide, M. Hodge, V., Flegal, A. R., Martin, J. (1983). U.S. mussel watch: 1977-1978 results on trace metals and radionuclides. Estuar. coast. Shelf Sci. 16: $69-93$

Gordon, M., Knauer, G. A., Martin, J. H. (1980). Mytilus californianus as a bioindicator of trace metal pollution: variability and statistical considerations. Mar. Pollut. Bull. 11: $195-198$

Hamilton, E. I., Clifton, R. J. (1980). Concentration and distribution of the transuranium radionuclides ${ }^{239+240} \mathrm{Pu}^{238} \mathrm{Pu}$ und ${ }^{241} \mathrm{Am}$ in Mytilus edulis, Fucus vesiculosis and sediment of Esk estuary. Mar. Ecol. Prog. Ser. 3: 267-277

Hood, D., Pytkowicz, R. M. (1974). Chemical oceanography. In: Walton-Smith, F. G. (ed.) Handbook of marine science 1. CRC Press, Cleveland, p. 1-70

IAEA (1985). Sediment Kds and concentration factors for radionuclides in the marine environment. Technical Reports Series No. 247, International Atomic Energy Agency, Vienna

Keckes, S., Pucar, Z., Marazovic, L. J. (1967). The influence of the physico-chemical form of Ru-106 on its uptake by mussels from seawater. In: Aberg, B., Hungate, F. P. (eds.) Radioecological concentration processes - Proc. Int. Symp. at Stockholm (April, 1966). Pergamon Press, Oxford, p. $993-994$

Koide, M., Lee, D. S., Goldberg, E. D. (1982). Metal and transuranic records in mussel shells, byssal threads and tissues. Estuar. coast. Shelf Sci. 15: 679-695

Lehninger, A. E. (1976). Biochemistry, 2nd edn. Worth Publishers Inc., New York

Lobel, P. B. (1987). Intersite, intrasite and inherent variability of the whole soft tissue zinc concentrations of individual 
mussels Mytilus edulis: importance of the kidney. Mar. environ. Res. 21: 59-71

Lobel, P. B., Mogie, P., Wright, D. A., Wu, B. L. (1982). Metal accumulation in four molluscs. Mar. Pollut. Bull. 13: $170-174$

Marchand, M., Vas, D., Duursma, E. K. (1976). Levels of PCBs and DDTs in mussels from the N.W. Mediterranean. Mar. Pollut. Bull. 7: 65-69

Martin, M., Stephenson, M. D., Smith, D. R., GutierrezGalindo, E. A., Munoz, G. O. (1988). Use of silver in mussels as a tracer of domestic wastewater discharge. Mar. Pollut. Bull. 19: 512-520

Mishima, J., Odum, E. P. (1983). Excretion rate of Zn-65 by Littorina irrorata in relation to temperature and body size. Limnol. Oceanogr. 8: 39-44

Nakahara, M., Koyanagi, T., Saiki, M. (1977). Temperature effect on the concentration of radionuclides by marine organisms. J. Radiat. Res. 18: 122-131

Pentreath, R. J. (1973). The accumulation from water of $\mathrm{Zn}-65$, Mn-54, Co-58 and Fe-59 by the mussel, Mytilus edulis. J. mar. biol. Ass. U.K. 53: 127-143

Phillips, D. J. H. (1976a). The common mussel Mytilus edulis as an indicator of pollution by zinc, cadmium, lead and copper. II. Relationship of metals in the mussel to those discharged by industry. Mar. Biol. 38: 71-80

Phillips, D. J. H. (1976b). The common mussel Mytilus edulis as an indicator of pollution by zinc, cadmium, lead and copper. I. Effects of environmental variables on uptake of metals. Mar. Biol. 38: 59-69

This article was submitted to the editor
Phillips, D. J. H. (1980). Quantitative aquatic biological indicators. Applied Science Publishers Ltd., London

Pringle, B. H., Hissong, D. E., Katz, E. L., Mulawka, S. T (1968). Trace metal accumulation by estuarine molluscs J. sanit. engng Div. A.m. Soc. Civ. Engs SA-3: 455-475

Ray, S. (1984). Bioaccumulation of cadmium in marine organisms. Experientia 40: 14

Rissgård, H. U., Randløv, A. (1981). Energy budgets, growth and filtration rates in Mytilus edulis at different algal concentrations. Mar. Biol. 61: 227-234

Shimizu, M. (1975). Procedures for radiological studies with molluscs. In: Design of radiotracer experiments in marine biological systems. IAEA, Vienna, p. 121-136

Shimizu, M., Tsuji, S. (1980). Heavy metal content of the common mussel, Mytilus edulis and its variation. In: Patel B. (ed.) Management of environment. Wiley Eastern Ltd. New Delhi, p. 409-416

Taguchi, M., Yasuda, K., Toda, S., Shimizu, M. (1979). Study of metal contents of elasmobranch fishes: Part 1 - metal concentration in the muscle tissues of a dogfish, Squalus mitsukurii. Mar. environ. Res. 2: 239-249

Wright, D. A. (1978). Heavy metal accumulation by aquatic invertebrates. Appl. Biol. 3: 331-394

Wright, D. A., Mihursky, J. A., Phelps, H. L. (1985). Trace metals in Chesapeake Bay oysters: intra-sample variability and its implications for biomonitoring. Mar. environ. Res. 16: $181-197$

Zeuthen, E. (1953). Oxygen uptake as related to body size in organisms. Q. Rev. Biol. 28: 1-12

Manuscript first received: August 6, 1990

Revised version accepted, December 11, 1990 